\title{
Thiohalospira halophila gen. nov., sp. nov. and Thiohalospira alkaliphila sp. nov., novel obligately chemolithoautotrophic, halophilic, sulfur-oxidizing gammaproteobacteria from hypersaline habitats
}

\author{
Correspondence \\ Dimitry Yu. Sorokin \\ soroc@inmi.host.ru \\ or \\ d.y.sorokin@tudelft.nl
}

\author{
Dimitry Yu. Sorokin, ${ }^{1}, 2$ Tatjana P. Tourova, ${ }^{1}$ Gerard Muyzer ${ }^{2}$ \\ and Gijs J. Kuenen² 7/2, 117811 Moscow, Russia
${ }^{2}$ Department of Biotechnology, Delft University of Technology, Julianalaan 67, 2628 BC Delft, The Netherlands \\ ${ }^{1}$ Winogradsky Institute of Microbiology, Russian Academy of Sciences, Prospect 60-let Octyabrya
}

\begin{abstract}
A previously unknown ecotype of obligately chemolithoautotrophic, sulfur-oxidizing bacteria was discovered in sediments of various inland hypersaline lakes and a solar saltern. The salt requirements for these bacteria were similar to those of haloarchaea, representing the first example of extreme halophiles occurring among the chemolithoautotrophs. They were enriched and isolated at $4 \mathrm{M} \mathrm{NaCl}$ under aerobic conditions with thiosulfate or tetrathionate as the electron donor or under micro-oxic conditions with sulfide. In total, 20 strains were obtained from hypersaline inland lakes in central Asia, central Russia and Crimea and a sea saltern of the Adriatic Sea. The isolates were thin, motile spirilla, some of which possessed a yellow, membrane-bound pigment. They were obligately aerobic, chemolithoautotrophic, sulfur-oxidizing bacteria that used thiosulfate, sulfide, sulfur and tetrathionate as electron donors. The characteristic feature of the group was the production of large amounts of tetrathionate as an intermediate during the oxidation of thiosulfate to sulfate. All but one of the strains grew within the $\mathrm{pH}$ range 6.5-8.2 (optimally at $\mathrm{pH} 7.3-7.8$ ) and at $\mathrm{NaCl}$ concentrations from 2.0 to $5 \mathrm{M}$ (optimally at $3.0 \mathrm{M}$ ). A single strain, designated ALgr $6 \mathrm{sp}^{\top}$, obtained (by enrichment) from the hypersaline alkaline lakes of the Wadi Natrun valley, was found to be moderately halophilic and facultatively alkaliphilic (capable of growth at $\mathrm{pH} 10$ ). The predominant cellular fatty acids were quite unusual, with 10 -methyl $\mathrm{C}_{16: 0}$ and $\mathrm{C}_{16 \text { : o }}$ predominating. Cells grown at $4 \mathrm{M} \mathrm{NaCl}$ accumulated extremely high concentrations of glycine betaine as a compatible solute. The 20 neutrophilic isolates contained three genospecies (on the basis of DNA-DNA relatedness data) but could not be discriminated phenotypically. On the basis of the phenotypic and genotypic analyses, the isolates constitute a novel genus and species, for which the name Thiohalospira halophila gen. nov., sp. nov. is proposed. The type strain of Thiohalospira halophila is $\mathrm{HL} 3^{\top}\left(=\mathrm{DSM} 15071^{\top}=\mathrm{UNIQEM} \mathrm{U} 219^{\mathrm{T}}\right)$. The haloalkaliphilic strain ALgr $6 \mathrm{sp}^{\top}$ represents a second species of the new genus, for which the name Thiohalospira alkaliphila sp. nov. is proposed. The type strain of Thiohalospira alkaliphila is ALgr $6 \mathrm{sp}^{\top}$ (=DSM $17116^{\top}=$ UNIQEM U372 ${ }^{\top}$ ).
\end{abstract}

Hypersaline habitats, such as inland salt lakes and solar salterns, are extreme habitats traditionally regarded as lowdiversity environments dominated by heterotrophic haloarchaea (Oren, 2002). However, this must be regarded as being true only of the brines; in the sediments, extreme

\section{Abbreviation: $\mathrm{SOB}$, sulfur-oxidizing bacteria.}

The GenBank/EMBL/DDBJ accession numbers for the 16S rRNA gene sequences determined in this study are DQ469576-DQ469579, EU169227 and EU368842-EU368850. and moderate halophiles with more versatile metabolisms replace the haloarchaea. In particular, the latter largely include representatives of the Gammaproteobacteria, such as moderately halophilic, heterotrophic members of the genera Halomonas and Marinobacter, which are better adapted to lower and fluctuating salinities (Ventosa et al., 1998), moderately halophilic sulfate-reducing bacteria (Kjeldsen et al., 2007) and the recently discovered extremely halophilic heterotrophic bacteria that form a phylogenetic cluster around the genus Halovibrio (former 
Pseudomonas halophila) (Sorokin et al., 2006a; Maturrano et al., 2006; Kharroub et al., 2006). Furthermore, chemolithoautotrophic sulfur-oxidizing bacteria (SOB) have the opportunity of adapting to extremely high-salt conditions, because they possess a very efficient energy metabolism (Oren, 1999). Recently, a large diversity of moderately, and even extremely, halophilic SOB have been detected in hypersaline habitats at neutral $\mathrm{pH}$ (Sorokin et al., 2006b). Of the six different types of halophilic SOB discovered, two groups of aerobic moderate halophiles were found to belong to the existing genera Thiomicrospira (Sorokin et al., 2006c) and Halothiobacillus. The other two groups of moderate halophiles included novel genera of denitrifying SOB, i.e. Thiohalophilus (Sorokin et al., 2007a) and Thiohalomonas (Sorokin et al., 2007b). The moderately halophilic SOB grew best at low salinities around 0.51.0 M NaCl but could tolerate quite high salinities (up to saturation). Previously, only a single species of SOB, Halothiobacillus halophilus, was known to be able to grow at $4 \mathrm{M} \mathrm{NaCl}$ (Wood \& Kelly, 1991). Furthermore, apart from moderately halophilic SOB, two novel, previously unknown chemolithoautotrophs, extremely halophilic SOB groups have been discovered in sediments from hypersaline habitats. One group was obligately aerobic and the other one was thiodenitrifying (Sorokin et al., 2006b).

The aerobic halophilic SOB described in this paper were obtained from samples of sediments from hypersaline lakes in NE Mongolia, SW Siberia and Crimea (Ukraine), from Lake Baskunchak (South Russia) and from the Sečovlje solar saltern (Slovenia) of the Adriatic Sea (Sorokin et al., 2006b). In general, the salt content of the brines varied from 10 to $38 \%(\mathrm{w} / \mathrm{v})$ and the $\mathrm{pH}$ ranged from 6.5 to 8.2; the predominant ions were $\mathrm{Na}^{+}, \mathrm{Mg}^{2+}, \mathrm{Cl}^{-}$and $\mathrm{SO}_{4}^{2-}$. One of the enrichments was also made with sediment samples from eight hypersaline alkaline lakes at Wadi El Natrun in Egypt. The lake brines there were predominantly of the chloride-sulfate type but also contained a fraction of sodium carbonates, which raised the $\mathrm{pH}$ to $9.0-10.0$ (Taher, 1999).

The mineral base medium used for the enrichment and growth experiments contained the following: $\mathrm{NaCl}$ $(4.0 \mathrm{M}), \mathrm{K}_{2} \mathrm{HPO}_{4}(10 \mathrm{mM})$ and $\mathrm{NH}_{4} \mathrm{Cl}(5 \mathrm{mM})$. The $\mathrm{pH}$ was adjusted to 7.2 with $10 \% \mathrm{KH}_{2} \mathrm{PO}_{4}$. After sterilization, the medium was supplemented with $2 \mathrm{mM} \mathrm{MgCl}_{2} \cdot 6 \mathrm{H}_{2} \mathrm{O}$ and $1 \mathrm{ml}$ trace metal solution $1^{-1}$ (Pfennig \& Lippert, 1966). Thiosulfate $(5-20 \mathrm{mM})$ or tetrathionate $(5 \mathrm{mM})$ was added as an electron donor from filter-sterilized $1 \mathrm{M}$ solutions. Filter-sterilized $\mathrm{NaHCO}_{3}(10-40 \mathrm{mM}$, pH 8.0) was used as the carbon source and as the $\mathrm{pH}$ buffer. Routine incubation was performed in closed bottles with a liquid/gas ratio of 10:90 to prevent loss of $\mathrm{CO}_{2}$ from the $\mathrm{NaHCO}_{3}$, leading to spontaneous alkalinization of the medium during the initial growth phase. With sulfide as the substrate, the principle of gradient cultivation (Nelson \& Jannasch, 1983) was employed using $50 \mathrm{ml}$ glass cylinders, with sulfide diffusing upward from the bottom $2 \%(\mathrm{w} / \mathrm{v})$ agar layer $(10 \mathrm{ml}, 0.1 \mathrm{mmol} \mathrm{Na} 2 \mathrm{~S})$ overlaid by
$30 \mathrm{ml}$ of the above-mentioned mineral medium with $3 \mathrm{M}$ $\mathrm{NaCl}$ containing five-times less trace elements (to slow down spontaneous oxidation) and $0.15 \%(w / v)$ Noble agar (Difco). For the Wadi Natrun enrichments, the $\mathrm{pH}$ was brought to 9.2 by the addition of $10 \% \mathrm{Na}_{2} \mathrm{CO}_{3}$. Oxygen diffused downwards from the $10 \mathrm{ml}$ headspace. The SOB usually developed within a thin layer of $1-2 \mathrm{~mm}, 1 \mathrm{~cm}$ below the surface of the top layer of medium. Cultivation was performed at $28{ }^{\circ} \mathrm{C}$. Growth was monitored by following the optical density at $600 \mathrm{~nm}$ and the consumption of substrate. Pure cultures were obtained after several rounds of serial dilution to extinction in liquid media, as neither of the isolates formed colonies on solid medium. The serial dilutions from sulfide gradient enrichments were done with thiosulfate in liquid medium but at $2 \%$ oxygen and with a liquid/gas ratio of $1: 20$. Culture purity was checked on rich organic medium in which the inorganic electron donor was replaced with yeast extract. Sulfur (sulfide, sulfur, thiosulfate, tetrathionate and sulfate) compounds were analysed as described previously (Sorokin et al., 2001). Cell protein was measured by using the Lowry method after the removal of interfering sulfur compounds either by washing (thiosulfate, tetrathionate) or by overnight extraction with acetone (sulfur). Phasecontrast microphotographs were obtained using Axioplan Imaging 2 (Zeiss). For electron microscopy, the cells were pre-fixed in glutaraldehyde (final concentration $3 \%$, v/v) at $\mathrm{pH} 7.0$ in the presence of $2 \mathrm{M} \mathrm{NaCl}$, then post-fixed in $1 \%(\mathrm{w} / \mathrm{v}) \mathrm{OsO}_{4} / 2.0 \mathrm{M} \mathrm{NaCl}$ for $12 \mathrm{~h}$ at room temperature, washed and stained overnight with $1 \%(\mathrm{w} / \mathrm{v})$ uranyl acetate, dehydrated in an ethanol series and then embedded in Epon resin. Lead citrate $(1 \%, \mathrm{w} / \mathrm{v})$ was used to provide contrast for thin sections.

Growth in enrichment cultures at $4 \mathrm{M} \mathrm{NaCl}$ was very slow, with full consumption of $20 \mathrm{mM}$ thiosulfate after 1 month. Because of this, initial attempts to find extremely halophilic SOB failed. Only after the prevention of an initial rise in the $\mathrm{pH}$ (above 8.0), through the use of static cultures in closed bottles, did it become possible to obtain positive results for most of the samples from the different geographical areas. This indicated the presence of indigenous SOB populations able to develop at saturating salt concentrations. In total, 14 strains were obtained from the aerobic enrichments with thiosulfate and tetrathionate and 6 strains were obtained from the sulfide-oxygen gradient cultures. A single strain was isolated on alkaline medium from a sulfide-oxygen gradient enrichment inoculated with sediments from the Wadi Natrun lakes. All 21 isolates were thin, motile spirilla with single bipolar flagella and Gramnegative type cell walls (Fig. 1). Some of the strains contained a membrane-bound yellow pigment that was extractable with methanol and had a spectrum (max. at $440 \mathrm{~nm}$ ) similar to those of natronochromes (xanthine-like polyenes found recently in extremely natronophilic $\mathrm{SOB}$ of the genus Thioalkalivibrio; Takaichi et al., 2004).

Cellular fatty acids were analysed using cells grown at $30{ }^{\circ} \mathrm{C}$ with $4 \mathrm{M} \mathrm{NaCl}$ and thiosulfate. Freeze-dried biomass was 

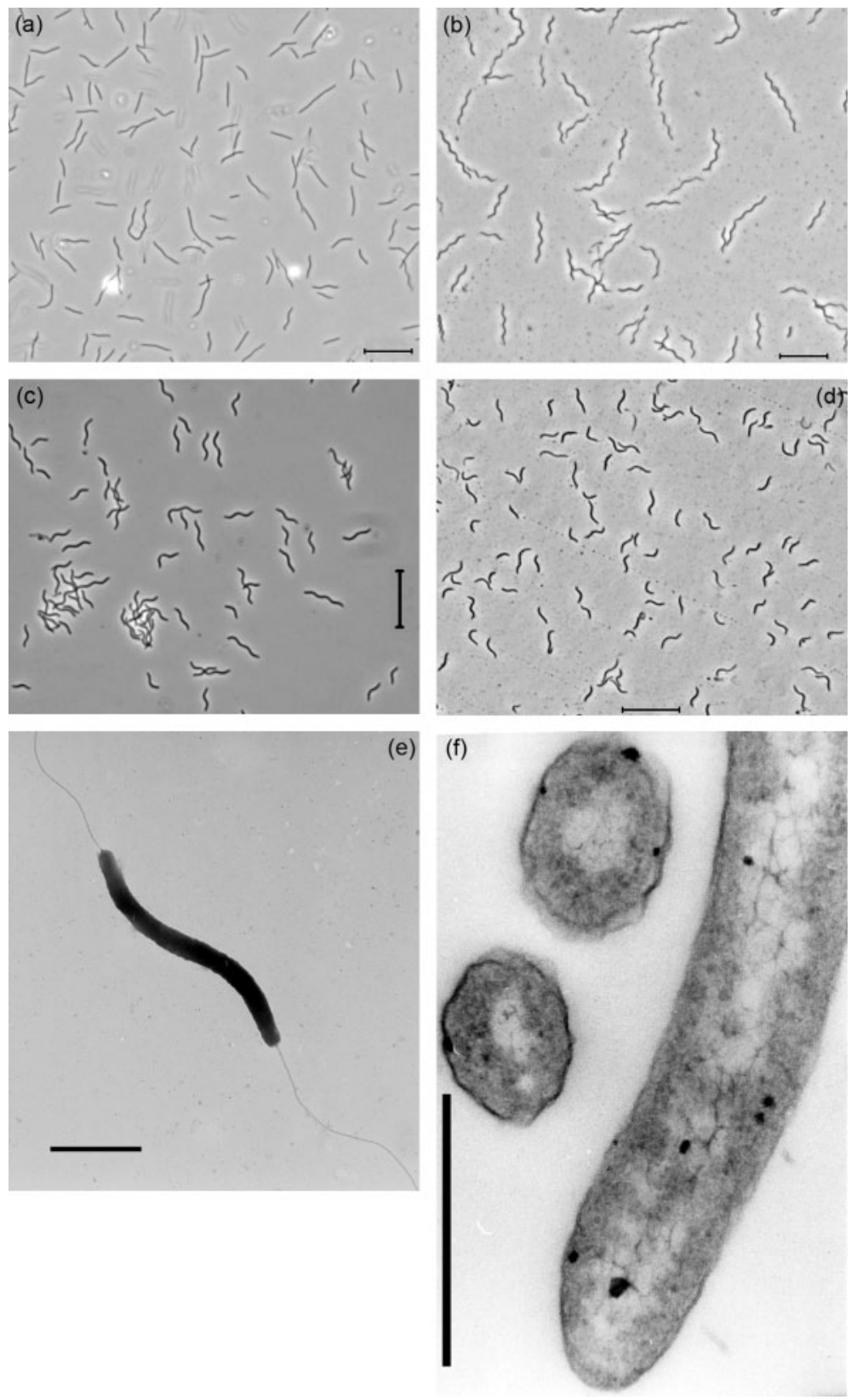

Fig. 1. Cell morphology of representative strains of the genus Thiohalospira grown at 2-4 M NaCl. (a-d) Phase-contrast microphotographs of strain $\mathrm{HL}^{\top}$ (a), strain $\mathrm{HL} 4(\mathrm{~b})$, strain $\mathrm{HL} 25$ (c) and strain ALgr 6sp ${ }^{\top}$ (d); (e and $f$ ) electron microphotographs of total preparation of strain $\mathrm{HL}^{\top}(\mathrm{e})$ and thin section of strain $\mathrm{HL} 3^{\top}(\mathrm{f})$. Bars, $10 \mu \mathrm{m}(\mathrm{a}-\mathrm{d}), 1 \mu \mathrm{m}$ (e and f). extracted with a methanol/chloroform mixture and was analysed by GC-MS according to the method described by Zhilina et al. (1997). Analysis of strains HL $3^{\mathrm{T}}$ and HL 4 demonstrated the complete predominance of saturated species: 10 -methyl $\mathrm{C}_{16: 0}, \mathrm{C}_{16: 0}$ and $\mathrm{C}_{18: 0}$ constituted more than $85 \%$ of the total and $\mathrm{C}_{16: 1} \omega 7$ and $\mathrm{C}_{18: 1} \omega 7$ made up the rest. Whereas $\mathrm{C}_{16: 0}$ often predominates in halophilic bacteria, the presence of 10-methyl $\mathrm{C}_{16: 0}$ as a predominant fatty acid of polar lipids is certainly unusual and may be unique to the novel bacteria. A spectroscopic analysis of cell fractions obtained from strains $\mathrm{HL} 3^{\mathrm{T}}$ and $\mathrm{HL} 4$ identified cytochrome $c_{554}$ as the major cytochrome, both in the membranes and in the soluble fractions, and revealed the presence of cytochrome $b_{561}$ in the membranes.
Organic compatible solutes were extracted from the freezedried cells grown at $4 \mathrm{M} \mathrm{NaCl}$ on mineral medium with thiosulfate (see above) and analysed using HPLC as described previously (Banciu et al., 2004). Analysis of strain $\mathrm{HL} 3^{\mathrm{T}}$ grown at $4 \mathrm{M} \mathrm{NaCl}$ on mineral medium with thiosulfate demonstrated the accumulation of a single compound, identified as glycine betaine, at an extremely high specific concentration (33\% of total cell mass). As no organic compounds were included in the medium, these results indicated the potential of the extremely halophilic $\mathrm{SOB}$ for de novo synthesis of glycine betaine.

The novel bacteria were obligately chemolithoautotrophic and obligately aerobic SOB, although the strains enriched 
with sulfide in gradient culture grew optimally at low oxygen ( $2 \%$ of the gas phase) and did not tolerate more than $10 \% \mathrm{O}_{2}$. In addition to growth with thiosulfate and sulfide, growth with tetrathionate and elemental sulfur was also possible. In all strains except ALgr $6 \mathrm{sp}^{\mathrm{T}}$, growth with thiosulfate occurred in two phases: during the initial phase more than $60 \%$ of the thiosulfate was converted to tetrathionate, which was eventually oxidized to sulfate: $2 \mathrm{~S}_{2} \mathrm{O}_{3}^{2-} \rightarrow \mathrm{S}_{4} \mathrm{O}_{6}^{2-} \rightarrow 4 \mathrm{SO}_{4}^{2-}$.

The rationale for thiosulfate conversion to tetrathionate is not clear for these neutrophilic SOB, in contrast to the mechanism in acidophiles, which use this method to protect the substrate from spontaneous degradation at low $\mathrm{pH}$ (Pronk et al., 1990). This reaction is catalysed by tetrathionate synthase (thiosulfate dehydrogenase) (Kelly \& Wood, 1994). High activity for this enzyme was found in cell-free extracts of strains $\mathrm{HL} 3^{\mathrm{T}}$ and $\mathrm{HL} 4$ with ferricyanide as an artificial acceptor [up to $5 \mu \mathrm{mol}$ (mg protein $\left.)^{-1} \min ^{-1}\right]$. The activity was located in the soluble fraction, most probably in the periplasm, as it was maximal at 3-4 M NaCl and dependent on both $\mathrm{Na}^{+}$and $\mathrm{Cl}^{-}$ions. The mechanism for tetrathionate conversion to sulfate was not so clear. In acidophiles, tetrathionate hydrolase has been found to convert tetrathionate to a mixture of thiosulfate, sulfur and sulfate (Pronk et al., 1990). In experiments with washed cells of strains HL $3^{\mathrm{T}}$ and HL 4, anaerobic incubation with tetrathionate yielded only thiosulfate and sulfate, suggesting disproportionation as opposed to hydrolysis. This requires further investigation. Strain ALgr $6 \mathrm{sp}^{\mathrm{T}}$ did not form tetrathionate from thiosulfate and showed very low levels of tetrathionate oxidation.

The most striking feature of the novel $\mathrm{SOB}$ was their extreme halophilism (except in the case of strain ALgr $6 \mathrm{sp}^{\mathrm{T}}$ ), which was evident from their dependence on salt for growth (Fig. 2a). In four of the strains tested, the $\mathrm{NaCl}$ range for growth was from $2-2.5$ to $4-5 \mathrm{M}$, with an optimum at $3 \mathrm{M}$. Such a salt range for growth has never before been observed in chemolithoautotrophic bacteria. Strain ALgr $6 \mathrm{sp}^{\mathrm{T}}$ had a profile typical of that of a moderate halophile. In contrast to growing cultures, washed cells of extremely halophilic strains were still active at salinities below $2 \mathrm{M}$, but the cells lysed rapidly at $\mathrm{NaCl}$ concentrations below $1 \mathrm{M}$ (Fig. 2b). The $\mathrm{pH}$ values suitable for growth of strains HL $3^{\mathrm{T}}$, HL 4 and HL 25 (from pH-neutral habitats) were found to be within the range 6.5-8.2, with an optimum between 7.3 and 7.8. In contrast, strain ALgr $6 \mathrm{sp}^{\mathrm{T}}$ (from Wadi Natrun) was able to grow at $\mathrm{pH}$ values up to 10.2 , with half of the $\mathrm{NaCl}$ being replaced by $\mathrm{NaHCO}_{3} /$ $\mathrm{Na}_{2} \mathrm{CO}_{3}$ on the basis of total [Na]. However, it still grew at neutral $\mathrm{pH}$ (down to 7.0) and had an optimum at $\mathrm{pH}$ 8.5. This identified the Wadi Natrun isolate as a facultatively alkaliphilic halophile (Fig. 2c).

Both the sodium ion and chloride were essential for growth of the novel SOB. Growth of strains HL $3^{\mathrm{T}}$ and HL 4 was arrested at just $25-30 \%$ replacement of the $\mathrm{NaCl}$ with $\mathrm{KCl}$ (a)

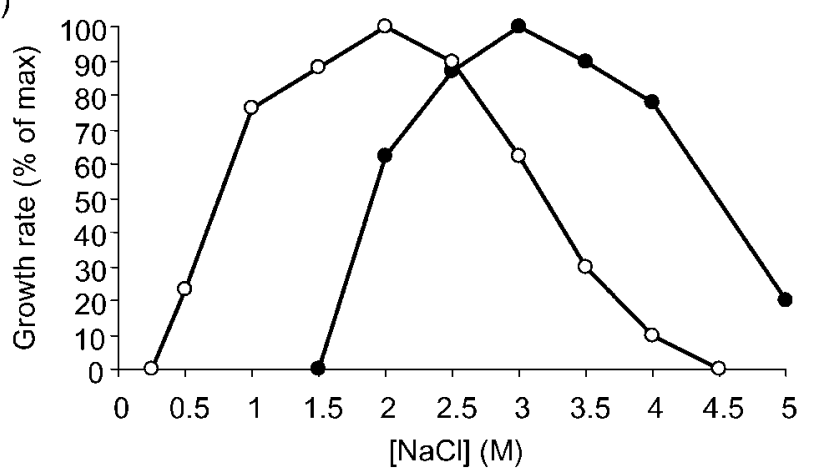

(b)

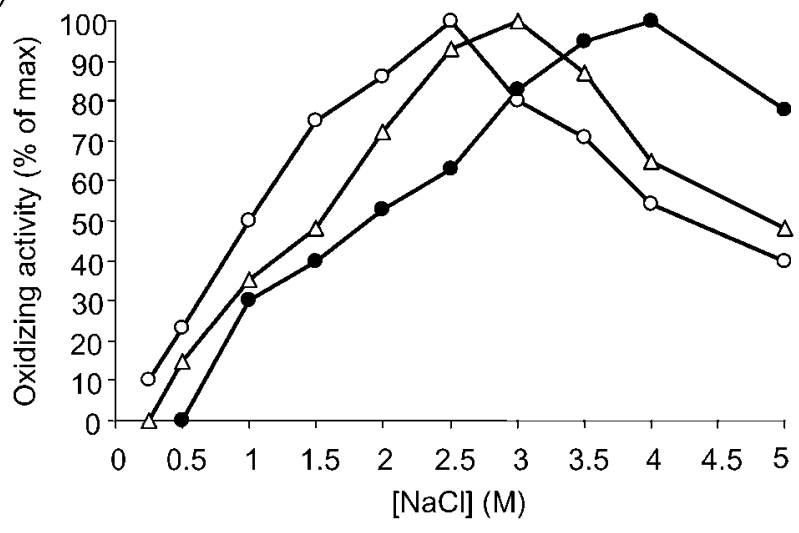

(c)

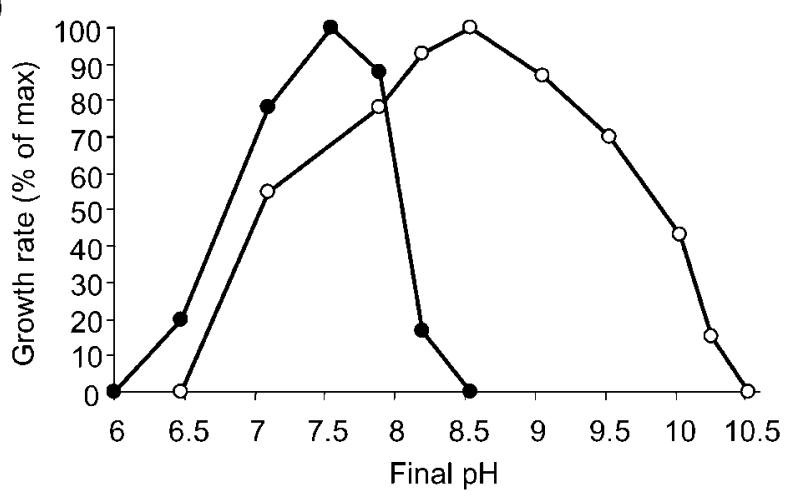

Fig. 2. Influence of $\mathrm{NaCl}$ on growth (a) of strain $\mathrm{HL} 3^{\top}$ at $\mathrm{pH} 7.5$ and strain $\mathrm{ALgr} 6 \mathrm{sp}^{\top}$ at $\mathrm{pH} 8.5$ with thiosulfate and on activity (b) of sulfur-compound oxidation by washed cells of strain $\mathrm{HL} 3^{\top}$ at $\mathrm{pH}$ 7.5. (c) pH profile for growth of strain $\mathrm{HL}^{\top}$ at $3 \mathrm{M} \mathrm{NaCl}$ and strain $\mathrm{ALgr} 6 \mathrm{sp}^{\top}$ at $2 \mathrm{M} \mathrm{NaCl}$ with thiosulfate. Symbols in (a) and (c): $\bigcirc$, strain $\mathrm{HL} 3^{\top} ; \bullet$, strain ALgr $6 s p^{\top}$. Symbols in (b): $\bullet$, thiosulfate oxidation to tetrathionate; $\bigcirc$, tetrathionate oxidation to sulfate; $\triangle$, sulfide oxidation. $100 \%$ specific growth rates for strains $\mathrm{HL} 3^{\top}$ and ALgr $6 \mathrm{sp}^{\top}$ were 0.04 and $0.07 \mathrm{~h}^{-1}$, respectively. $100 \%$ activities for thiosulfate, tetrathionate and sulfide oxidation were 650,340 and $620 \mathrm{nmol} \mathrm{O}_{2}$ (mg protein) ${ }^{-1} \mathrm{~min}^{-1}$, respectively.

at $3 \mathrm{M}$ total salt (i.e. $2 \mathrm{M} \mathrm{NaCl} / 1 \mathrm{M} \mathrm{KCl}$ ). The minimum requirement for $\mathrm{K}^{+}$was very low $(1 \mathrm{mM})$. Sodium chloride substitution by sodium sulfate had a less dramatic result, with full growth occurring at up to $50 \%$ chloride 
substitution (by charge, $2 \mathrm{Cl}^{-}=1 \mathrm{SO}_{4}^{2-}$; i.e. $1.5 \mathrm{M} \mathrm{NaCl} /$ $0.75 \mathrm{M} \mathrm{Na}_{2} \mathrm{SO}_{4}$ ). The minimum chloride requirement (at $3 \mathrm{M} \mathrm{Na}^{+}$) for initiating growth was $1 \mathrm{M}$. However, the activity of washed cells was much less sensitive to sodium replacement with potassium $(50 \%$ activity at $50 \%$ substitution) and chloride substitution by sulfate $(100 \%$ activity at up to $70 \%$ substitution by charge). In the case of high potassium, however, almost all of the cells had lysed by the end of a $2 \mathrm{~h}$ experiment.

The genomic DNA was extracted by using the phenol/ chloroform method (Marmur, 1961). The G $+\mathrm{C}$ analysis and DNA-DNA hybridization were performed by using the thermal denaturation/reassociation technique (Marmur \& Doty, 1962; De Ley et al., 1970) with Escherichia coli as a standard. DNA-DNA hybridization showed that the isolates could be grouped into four genomic species (Table 1). Most of them clustered with strain HL $3^{\mathrm{T}}$, with DNA-DNA relatedness values above $70 \%$, whereas the isolates from Mongolia (HL 4) and the Adriatic Sea saltern had relatedness values of only $45-55 \%$ with the main cluster, despite the absence of any significant phenotypic differences. Isolate ALgr $6 \mathrm{sp}^{\mathrm{T}}$ from Wadi Natrun was genotypically most distant from the rest (showing no more than $40 \%$ DNA-DNA relatedness).

The almost-complete 16S rRNA gene was amplified from pure cultures using bacterial primers GM3F and GM4R (Schäfer \& Muyzer, 2001). The PCR products were purified from low-melting-point agarose by using a Wizard PCRPrep kit (Promega) according to the manufacturer's instructions. Sequencing was performed using a BigDye Terminator version 3.1 sequencing reaction kit with an ABI 3730 DNA automatic sequencer (Applied Biosystems). The sequences were aligned with those from GenBank using
CLUSTAL W (Thompson et al., 1994). Phylogenetic trees were reconstructed with four different algorithms by using the software packages TREECON W (van de Peer \& De Wachter, 1994) and PHYLIP, version 3.5c (Felsenstein, 1993). Pairwise evolutionary distances (expressed as estimated changes per $100 \mathrm{nt}$ ) were computed by using the JukesCantor method (Jukes \& Cantor, 1969). Because the topologies were very similar for all four types of phylogenetic tree (i.e. neighbour-joining, maximum-parsimony, distance matrix and maximum-likelihood), the final result is represented by a phylogenetic tree constructed using the neighbour-joining method (Fig. 3). Bootstrap analysis (1000 replications) was used to validate the reproducibility of the branching patterns of the trees. Analysis of the representative strains from four genomic species demonstrated that they indeed formed a compact group representing a novel lineage in the Gammaproteobacteria clustering with members of the family Ectothiorhodospiraceae. The sequence similarity between the extremely halophilic strains was $98.5-99.7 \%$ and that between extremely halophilic strains and the moderately halophilic alkaliphilic strain ALgr $6 \mathrm{sp}^{\mathrm{T}}$ was 93.5-94.6\%. The most closely related culturable representative of the halophilic SOB within the Gammaproteobacteria were members of the genus Thioalkalivibrio (90.0-93.1\% sequence similarity).

The data presented demonstrate the unique features of the novel group of SOB isolated from hypersaline habitats. On the basis of genetic properties, the 21 isolates can be separated into four genomic species. However, only two species could be clearly discriminated phenotypically and phylogenetically: one included extremely halophilic isolates isolated from neutral habitats and the other was repre-

Table 1. Pure cultures of halophilic aerobic SOB enriched and isolated at $3-4 \mathrm{M} \mathrm{NaCl}$

\begin{tabular}{|c|c|c|c|c|c|c|c|c|}
\hline \multirow[t]{2}{*}{ Geographic region } & \multirow{2}{*}{$\begin{array}{l}\text { Source of } \\
\text { isolation }\end{array}$} & \multirow{2}{*}{$\begin{array}{l}\text { No. of } \\
\text { strains }\end{array}$} & \multirow{2}{*}{$\begin{array}{c}\text { Strain } \\
\text { designation }(s)\end{array}$} & \multirow{2}{*}{$\begin{array}{l}\text { DNA G+C } \\
\text { content } \\
(\mathrm{mol} \%)\end{array}$} & \multicolumn{4}{|c|}{ No. of strains in: } \\
\hline & & & & & $\begin{array}{l}\text { Genomic } \\
\text { group }^{\star} \\
\text { HL } 3^{T}\end{array}$ & $\begin{array}{l}\text { Genomic } \\
\text { group } \\
\text { HL } 4\end{array}$ & $\begin{array}{l}\text { Genomic } \\
\text { group } \\
\text { HL } 25\end{array}$ & $\begin{array}{c}\text { Genomic } \\
\text { group } \\
\text { ALgr } 6 \mathrm{sp}^{\mathrm{T}}\end{array}$ \\
\hline $\begin{array}{l}\text { Kulunda Steppe (SW } \\
\text { Siberia, Altai, Russia) }\end{array}$ & Salt lakes & 15 & $\begin{array}{l}\text { HL } 3^{\mathrm{T}}, \text { HL 9-HL } \\
16, \text { HL } 18 \dagger, \text { HL } \\
22 \dagger, \text { HLgr1- } \\
\text { HLgr5 } \ddagger\end{array}$ & $65.8-67.0$ & 15 & & & \\
\hline NE Mongolia & Salt lakes & 2 & HL $4 \dagger$, HL $21 \dagger$ & 67.0 & 1 & 1 & & \\
\hline $\begin{array}{l}\text { Lake Baskunchak (South } \\
\text { Russia) }\end{array}$ & Salt lakes & 1 & HL 23 & 65.8 & 1 & & & \\
\hline Crimea (Ukraine) & Salt lakes & 1 & HL 24 & 66.5 & 1 & & & \\
\hline Slovenia, Adriatic & Saltern & 1 & HL 25 & 66.0 & & & 1 & \\
\hline
\end{tabular}

${ }^{*}$ Genetic groups HL $3{ }^{\mathrm{T}}$, HL 4 and HL 25 shared DNA-DNA relatedness of around $50 \%$ and showed less than $40 \%$ DNA-DNA relatedness with respect to ALgr $6 \mathrm{sp}^{\mathrm{T}}$.

$\dagger$ Produces membrane-bound yellow pigment.

$\ddagger$ Enriched using sulfide-oxygen gradient culture. 


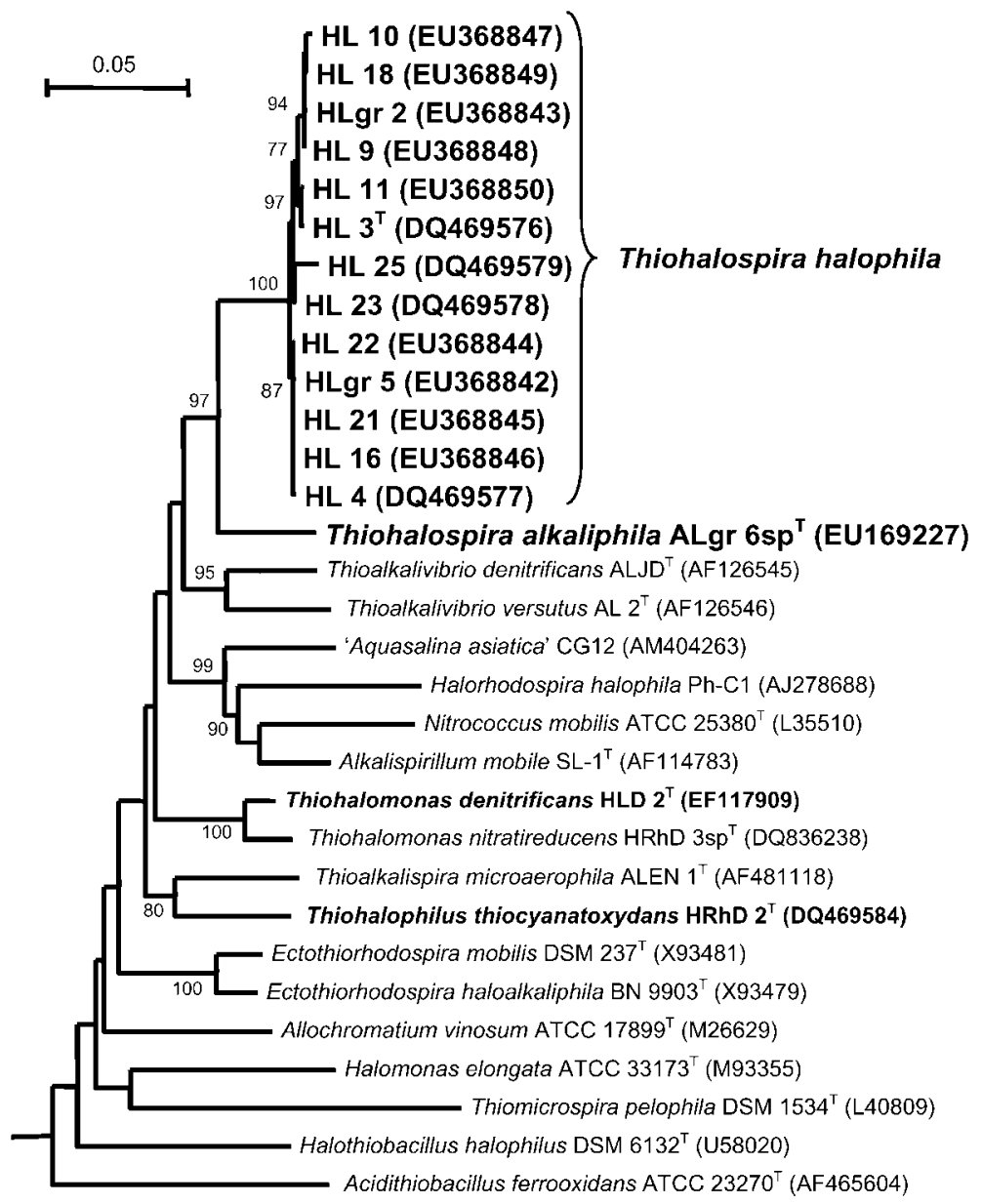

Fig. 3. Neighbour-joining phylogenetic tree, based on 16S rRNA gene sequences, showing the position of halophilic aerobic SOB of the genus Thiohalospira from hypersaline habitats within the Gammaproteobacteria. Bootstrap percentages were derived from 1000 resamplings; values greater than $70 \%$ were considered as significant. Names shown in bold belong to a group of moderately halophilic SOB isolated from the same habitats (Sorokin et al., 2006b). Bar, 0.05 substitutions per nucleotide position. sented by a moderately halophilic, facultative akaliphile isolated from the alkaline hypersaline lakes of Wadi Natrun in Egypt. The extreme halophiles represent a novel genus and species, for which the name Thiohalospira halophila gen. nov., sp. nov. is proposed. A second novel species of this new genus, Thiohalospira alkaliphila sp. nov., is proposed for the facultatively alkaliphilic strain ALgr $6 \mathrm{sp}^{\mathrm{T}}$.

\section{Description of Thiohalospira gen. nov.}

Thiohalospira (Thi.o.ha'lo.spi'ra. Gr. n. thion sulfur; Gr. n. hals, halos salt of the sea; L. fem. n. spira spiral; N.L. fem. n. Thiohalospira halophilic sulfur spirillum).

Motile spirilla with Gram-negative type of cell wall. Obligately chemolithoautotophic, aerobic, sulfur-oxidizing bacteria. Oxidize inorganic sulfur compounds to sulfate. Tetrathionate is the usual intermediate of thiosulfate oxidation. Includes extremely halophilic, neutrophilic and moderately halo(alkali)philic bacteria. Cellular fatty acids are dominated by saturated $\mathrm{C}_{16}-\mathrm{C}_{18}$ species. Isolated from hypersaline habitats. A member of the family Ectothiorhodospiraceae in the Gammaproteobacteria. The type species is Thiohalospira halophila.

\section{Description of Thiohalospira halophila sp. nov.}

Thiohalospira halophila (ha.lo'phi.la. Gr. n. hals salt; Gr. adj. philos loving; N.L. fem. adj. halophila salt-loving).

Exhibits the following properties in addition to those given in the genus description. Cells are spirilla of variable length, $0.4-0.5 \times 2-8 \mu \mathrm{m}$, with single bipolar flagella. A membrane-bound yellow pigment can be present. Predominant cellular fatty acids are 10-methyl $\mathrm{C}_{16: 0}, \mathrm{C}_{16: 0}$ and $\mathrm{C}_{18: 0 \text {. }}$ Accumulates glycine betaine as a compatible solute. Oxidizes thiosulfate to sulfate via tetrathionate. Also utilizes sulfide and elemental sulfur. Can be obligate microaerophiles. Extremely halophilic, with a salinity range for growth of 2.0-5.0 M NaCl and an optimum at 2.53.0 M. Requires high concentrations of both $\mathrm{Na}^{+}$and $\mathrm{Cl}^{-}$. $\mathrm{pH}$ range for growth is between 6.5 and 8.2, with an optimum at $\mathrm{pH} 7.3-7.8$. Optimum growth temperature is $32-35{ }^{\circ} \mathrm{C}$. The DNA $\mathrm{G}+\mathrm{C}$ content is $65.8-67.0 \mathrm{~mol} \%$ $\left(T_{\mathrm{m}}\right)$ and that of the type strain is $65.8 \mathrm{~mol} \%\left(T_{\mathrm{m}}\right)$.

The type strain, HL $3^{\mathrm{T}} \quad\left(=\mathrm{DSM} \quad 15071^{\mathrm{T}}=\mathrm{UNIQEM}\right.$ $\mathrm{U} 219^{\mathrm{T}}$ ), was isolated from a hypersaline lake in SW Siberia (Russia). Includes another 19 strains isolated from sediments of hypersaline lakes and a solar saltern in Eurasia. 


\section{Description of Thiohalospira alkaliphila sp. nov.}

Thiohalospira alkaliphila [al.ka.li.phi'la. M.L. n. alkali soda ash (from Arabic al-qalyi the ashes of saltwort); Gr. adj. philos loving; N.L. fem. adj. alkaliphila loving alkaline conditions].

Exhibits the following properties in addition to those given in the genus description. Cells are spirilla of variable length, $0.4-0.5 \times 2-4 \mu \mathrm{m}$, with single polar flagella. Cells contain high concentrations of a yellow pigment in the membranes. Obligately microaerophilic; no growth occurs above $10 \%$ $\mathrm{O}_{2}$ in the gas phase, the optimum concentration being $2 \%$. Oxidizes thiosulfate and sulfide to sulfate with the occasional formation of elemental sulfur. Does not produce tetrathionate from thiosulfate. Moderately halophilic, with a salinity range for growth from 0.5 to $4.0 \mathrm{M}$ $\mathrm{NaCl}$ and an optimum at $2.0 \mathrm{M}$. Requires high concentrations of both $\mathrm{Na}^{+}$and $\mathrm{Cl}^{-}$. Facultatively alkaliphilic with a $\mathrm{pH}$ range for growth between 7.0 and 10.2 and an optimum at $\mathrm{pH}$ 8.5. Optimum growth temperature is $35{ }^{\circ} \mathrm{C}$. The DNA $\mathrm{G}+\mathrm{C}$ content of the type strain is $65.6 \mathrm{~mol} \%\left(T_{\mathrm{m}}\right)$.

The type strain, ALgr $6 \mathrm{sp}^{\mathrm{T}}\left(=\mathrm{DSM} 17116^{\mathrm{T}}=\mathrm{UNIQEM}\right.$ $\left.\mathrm{U} 372^{\mathrm{T}}\right)$, was isolated from sediments of hypersaline alkaline lakes at Wadi El Natrun in Egypt by means of sulfide-oxygen gradient cultivation.

\section{Acknowledgements}

This work was supported by the NWO-RFBR (grant 47.011.2004.010), the RFBR (grant 07-04-00153) and by the 'Molecular and Cell Biology' program of the Russian Academy of Sciences. We thank E. Galinski and M. Stein for the analysis of compatible solutes, G. Osipov for the analysis of cellular fatty acids and K. Sjollema for the electron microscopy of thin sections.

\section{References}

Banciu, H., Sorokin, D. Yu., Galinski, E. A., Muyzer, G., Kleerebezem, R. \& Kuenen, J. G. (2004). Thioalkalivibrio halophilus sp. nov., a novel obligately chemolithoautotrophic facultatively alkaliphilic and extremely salt-tolerant sulfur-oxidizing bacterium from a hypersaline alkaline lake. Extremophiles 8, 325-334.

De Ley, J., Cattoir, H. \& Reynaerts, A. (1970). The quantitative measurement of DNA hybridization from renaturation rates. Eur $J$ Biochem 12, 133-142.

Felsenstein, J. (1993). PHYLIP (phylogeny inference package), version 3.53c. Distributed by the author. Department of Genome Sciences, University of Washington, Seattle, USA.

Jukes, T. H. \& Cantor, C. R. (1969). Evolution of protein molecules. In Mammalian Protein Metabolism, vol. 3, pp. 21-132. Edited by H. N. Munro. New York: Academic Press.

Kelly, D. P. \& Wood, A. P. (1994). Enzymes involved in microbiological oxidation of thiosulfate and polythionates. Methods Enzymol 243, 501-520.

Kharroub, K., Aguilera, M., Quesada, T., Morillo, J. A., RamosCormenzana, A., Boulharouf, A. \& Monteoliva-Sánchez, M. (2006). Salicola salis sp. nov., an extremely halophilic bacterium isolated from Ezzemoul sabkha in Algeria. Int J Syst Evol Microbiol 56, 2647-2652.
Kjeldsen, K. U., Loy, A., Jakobsen, T. F., Thomsen, T. R., Wagner, M. \& Ingvorsen, K. (2007). Diversity of sulfate-reducing bacteria from an extreme hypersaline sediment, Great Salt Lake (Utah). FEMS Microbiol Ecol 60, 287-298.

Marmur, J. (1961). A procedure for the isolation of deoxyribonucleic acid from microorganisms. J Mol Biol 3, 208-218.

Marmur, J. \& Doty, P. (1962). Determination of the base composition of deoxyribonucleic acid from microorganisms. J Mol Biol 5, 109-118.

Maturrano, L., Valens-Vadell, M., Rosselló-Mora, R. \& Antón, J. (2006). Salicola marasensis gen. nov., sp. nov., an extremely halophilic bacterium isolated from the Maras solar salterns in Peru. Int J Syst Evol Microbiol 56, 1685-1691.

Nelson, D. C. \& Jannasch, H. W. (1983). Chemoautotrophic growth of a marine Beggiatoa in sulfide-gradient cultures. Arch Microbiol 136, 262-269.

Oren, A. (1999). Bioenergetic aspects of halophilism. Microbiol Mol Biol Rev 63, 334-348.

Oren, A. (2002). Halophilic Microorganisms and Their Environments. Dordrecht: Kluwer AP.

Pfennig, N. \& Lippert, K. D. (1966). Über das Vitamin $B_{12}-$ Bedürfnis phototropher Schwefelbacterien. Arch Microbiol 55, 245-256 (in German).

Pronk, J. T., Meulenberg, R., Hazeu, W., Bos, P. \& Kuenen, J. G. (1990). Oxidation of reduced inorganic sulfur compounds by acidophilic thiobacilli. FEMS Microbiol Rev 75, 293-306.

Schäfer, H. \& Muyzer, G. (2001). Denaturing gradient gel electrophoresis in marine microbial ecology. Methods Microbiol 30, 426-468.

Sorokin, D. Yu., Kuenen, J. G. \& Jetten, M. (2001). Denitrification at extremely alkaline conditions in obligately autotrophic alkaliphilic sulfur-oxidizing bacterium Thioalkalivibrio denitrificans. Arch Microbiol 175, 94-101.

Sorokin, D. Yu., Tourova, T. P., Galinski, E. A., Belloch, C. \& Tindall, B. J. (2006a). Extremely halophilic denitrifying bacteria from hypersaline inland lakes, Halovibrio denitrificans sp. nov. and Halospina denitrificans gen. nov., sp. nov., and evidence that the genus name Halovibrio Fendrich 1989 with the type species Halovibrio variabilis should be associated with DSM 3050. Int J Syst Evol Microbiol 56, 379-388.

Sorokin, D. Yu., Tourova, T. P., Lysenko, A. M. \& Muyzer, G. (2006b). Culturable diversity of halophilic sulfur-oxidizing bacteria in hypersaline habitats. Microbiology 152, 3013-3023.

Sorokin, D. Yu., Tourova, T. P., Kolganova, T. V., Spiridonova, E. M., Berg, I. A. \& Muyzer, G. (2006c). Thiomicrospira halophila sp. nov., a novel, moderately halophilic, obligately chemolithoautotrophic sulfur-oxidizing bacterium from hypersaline lakes. Int J Syst Evol Microbiol 56, 2375-2380.

Sorokin, D. Y., Tourova, T. P., Bezsoudnova, E. Y., Pol, A. \& Muyzer, G. (2007a). Denitrification in a binary culture and thiocyanate metabolism in Thiohalophilus thiocyanoxidans gen. nov. sp. nov. - a moderately halophilic chemolithoautotrophic sulfuroxidizing Gammaproteobacterium from hypersaline lakes. Arch Microbiol 187, 441-450.

Sorokin, D. Yu., Tourova, T. P., Bracker, G. \& Muyzer, G. (2007b). Thiohalomonas denitrificans gen. nov., sp. nov, and Thiohalomonas nitratireducens sp. nov., novel obligately chemolithoautotrophic, moderately halophilic, thiodenitrifying Gammaproteobacteria from hypersaline habitats. Int J Syst Evol Microbiol 57, 1582-1589.

Taher, A. G. (1999). Inland saline lakes of Wadi El Natrun depression, Egypt. Int J Salt Lake Res 8, 149-170.

Takaichi, S., Maoka, T., Akimoto, N., Sorokin, D. Yu., Banciu, H. \& Kuenen, J. G. (2004). Two novel yellow pigments natronochrome and chloronatronochrome from the natrono(alkali)philic sulfur-oxidizing 
bacterium Thialkalivibrio versutus ALJ 15. Tetrahedron Lett 45, 8303-8305.

Thompson, J. D., Higgins, D. G. \& Gibson, T. J. (1994). CLUSTAL W: improving the sensitivity of progressive multiple sequence alignment through sequence weighting, position-specific gap penalties and weight matrix choice. Nucleic Acids Res 22, 4673-4680.

Van de Peer, Y. \& De Wachter, R. (1994). TREECON for Windows: a software package for the construction and drawing of evolutionary trees for the Microsoft Windows environment. Comput Appl Biosci 10, 569-570.
Ventosa, A., Nieto, J. J. \& Oren, A. (1998). Biology of aerobic moderately halophilic bacteria. Microbiol Mol Biol Rev 62, 504-544.

Wood, A. P. \& Kelly, D. P. (1991). Isolation and characterisation of Thiobacillus halophilus sp. nov., a sulphur-oxidizing autotrophic eubacterium from a Western Australian hypersaline lake. Arch Microbiol 156, 277-280.

Zhilina, T. N., Zavarzin, G. A., Rainey, F. A., Pikuta, E. N., Osipov, G. A. \& Kostrikina, N. A. (1997). Desulfonatronovibrio hydrogenovorans gen. nov., sp. nov., an alkaliphilic, sulfate-reducing bacterium. Int J Syst Bacteriol 47, 144-149. 